Atmos. Chem. Phys., 18, 16409-16418, 2018

https://doi.org/10.5194/acp-18-16409-2018

(C) Author(s) 2018. This work is distributed under

the Creative Commons Attribution 4.0 License.

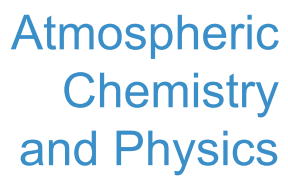

(c) (P)

\title{
Chemical characteristics of brown carbon in atmospheric particles at a suburban site near Guangzhou, China
}

\author{
Yi Ming Qin ${ }^{1, a, b}$, Hao Bo Tan ${ }^{2}$, Yong Jie $\mathrm{Li}^{3}$, Zhu Jie $\mathrm{Li}^{2,4}$, Misha I. Schurman ${ }^{5, \mathrm{c}}$, Li Liu ${ }^{2,6}$, Cheng Wu ${ }^{7}$, and \\ Chak K. Chan ${ }^{1, b, c}$ \\ ${ }^{1}$ School of Energy and Environment, City University of Hong Kong, Hong Kong, China \\ ${ }^{2}$ Key Laboratory of Regional Numerical Weather Prediction, Institute of Tropical and Marine Meteorology, \\ China Meteorological Administration, Guangzhou, China \\ ${ }^{3}$ Department of Civil and Environmental Engineering, Faculty of Science and Technology, \\ University of Macau, Macau, China \\ ${ }^{4}$ School of Environmental Science and Engineering, Nanjing University of Information Science \\ and Technology, Nanjing, China \\ ${ }^{5}$ Zephyr Research Consultants, Leadville, CO, USA \\ ${ }^{6}$ Department of Atmospheric Science, Sun yat-sen University, Guangzhou, China \\ ${ }^{7}$ Institute of Mass Spectrometer and Atmospheric Environment, Jinan University, Guangzhou, China \\ a now at: School of Engineering and Applied Sciences, Harvard University, Cambridge, MA, USA \\ ${ }^{b}$ formerly at: Department of Chemical and Biomolecular Engineering, Hong Kong University of Science and Technology, \\ Hong Kong, China \\ ${ }^{\mathrm{c}}$ formerly at: Division of Environment, Hong Kong University of Science and Technology, Hong Kong, China
}

Correspondence: Chak K. Chan (chak.k.chan@cityu.edu.hk) and Yong Jie Li (yongjieli@umac.mo)

Received: 17 July 2018 - Discussion started: 26 July 2018

Revised: 29 October 2018 - Accepted: 1 November 2018 - Published: 19 November 2018

\begin{abstract}
Light-absorbing organic carbon (or brown carbon, $\mathrm{BrC}$ ) in atmospheric particles has received much attention for its potential role in global radiative forcing. While a number of field measurement campaigns have differentiated light absorption by black carbon (BC) and $\mathrm{BrC}$, the chemical characteristics of $\mathrm{BrC}$ are not well understood. In this study, we present co-located real-time light absorption and chemical composition measurements of atmospheric particles to explore the relationship between the chemical and optical characteristics of $\mathrm{BrC}$ at a suburban site downwind of Guangzhou, China, from November to December 2014. $\mathrm{BrC}$ and $\mathrm{BC}$ contributions to light absorption were estimated using measurements from a seven-wavelength aethalometer, while the chemical composition of non-refractory $\mathrm{PM}_{1}$ was measured with a high-resolution time-of-flight aerosol mass spectrometer (HR-ToF-AMS). Using the absorption Ångström exponent (AAE) method, we estimated that $\mathrm{BrC}$ contributed $23.6 \%$ to the total aerosol absorption at $370 \mathrm{~nm}$, $18.1 \%$ at $470 \mathrm{~nm}, 10.7 \%$ at $520 \mathrm{~nm}, 10.7 \%$ at $590 \mathrm{~nm}$, and
\end{abstract}

$10.5 \%$ at $660 \mathrm{~nm}$. Biomass burning organic aerosol (BBOA) has the highest mass absorption coefficient among sources of organic aerosols. Its contribution to total brown carbon absorption coefficient decreased but that of low-volatility oxygenated organic aerosol (LVOOA) increased with increasing wavelength, suggesting the need for wavelengthdependent light absorption analysis for $\mathrm{BrC}$ in association with its chemical makeup. Clear correlations of $\mathrm{N}$-containing ion fragments with absorption coefficient were observed. These correlations also depended on their degrees of unsaturation/cyclization and oxygenation. While the current study relates light absorption by $\mathrm{BrC}$ to ion fragments, more detailed chemical characterization is warranted to constrain this relationship. 


\section{Introduction}

Atmospheric particles participate considerably in the global climate direct effect via their light-scattering (e.g., sulfate) and/or light-absorbing components (e.g., black carbon, BC). $\mathrm{BC}$ is a major contributor to light absorption that leads to positive radiative forcing, increasing the average temperature of the atmosphere. The $\mathrm{BrC}$ absorption contribution to total aerosol light absorption can reach $20 \%-50 \%$ over regions dominated by seasonal biomass burning and biofuel combustion (Feng et al., 2013). A significant difference in the optical features of $\mathrm{BrC}$ and $\mathrm{BC}$ is that $\mathrm{BrC}$ absorbs light primarily at $\mathrm{UV}$ and short visible wavelengths with the absorption decreasing significantly at long wavelengths, while $\mathrm{BC}$ absorbs strongly and constantly throughout the UV to visible spectrum (Andreae and Gelencsér, 2006; Bergstrom et al., 2007; Bond and Bergstrom, 2006). In global climate models, the direct radiative forcing of organic aerosols at the top of the atmosphere can shift from cooling $\left(-0.08 \mathrm{Wm}^{-2}\right)$ to warming $\left(+0.025 \mathrm{Wm}^{-2}\right)$ when strong $\mathrm{BrC}$ absorption is included (Feng et al., 2013). However, uncertainties in the sources, formation, chemical composition, and absorption properties of $\mathrm{BrC}$ hinder more accurate estimations of radiative forcing induced by atmospheric particles.

$\mathrm{BrC}$ is operationally defined and has many chemical constituents, which makes chemical characterization quite challenging. Both primary and secondary organic aerosols can act as BrC (Laskin et al., 2015). For example, biomass burning organic aerosol (BBOA) has been identified as a contributor to $\mathrm{BrC}$ in rural areas in the southern United States, while coal combustion organic aerosol (CCOA) contributes substantially to $\mathrm{BrC}$ during winter in Beijing (Yan et al., 2017). Species from secondary formation processes, such as humic-like substances (HULIS) formed by in-cloud processing (Rincón et al., 2009), species from gas-phase photooxidation of volatile organic compounds (VOCs) in the presence of $\mathrm{NO}_{x}$, and species from reactions between carbonyl compounds and ammonia in the aqueous film at the particle surface, can also contribute to $\mathrm{BrC}$ (Gen et al., 2018; Laskin et al., 2010; Liu et al., 2015). Highly conjugated organics, nitro-aromatic compounds, imidazoles, and other $\mathrm{N}$ heterocyclic compounds have been found in $\mathrm{BrC}$ (Laskin et al., 2015; Lin et al., 2016). Sun et al. (2007) also found that light-absorbing organic molecules in $\mathrm{BrC}$ are likely large (i.e., possessing $>18$ carbon atoms); these molecules are generally highly unsaturated and contain three or more oxygen atoms and/or one or more nitrogen atoms.

The Pearl River Delta (PRD) region, one of the most economically developed regions in China, suffers under air pollution from a variety of sources (Chan and Yao, 2008; Li et al., 2017). Source apportionment using positive matrix factorization (PMF) analysis of mass spectral data sets from a high-resolution time-of-flight aerosol mass spectrometer (HR-ToF-AMS) has revealed that the organic aerosol (OA) in this region arises from traffic emissions (i.e., hydrocarbon- like organic aerosol, or HOA), biomass burning (BBOA), cooking (COA), and secondary formation (i.e., oxygenated organic aerosols, or OOAs). In the PRD, HOA is often the largest contributor to OA at urban sites (He et al., 2011), while SOA plays a more important role at rural sites (Gong et al., 2012; Huang et al., 2011). BBOA has also been found to contribute significantly to total OA in the PRD region, with contributions of $24 \%$ at an urban site in Shenzhen (He et al., 2011) and $14 \%$ and $25 \%$ at rural sites in Heshan and Kaiping, respectively (Gong et al., 2012; Huang et al., 2011). Yuan et al. (2016) attributed 6\%-12\% of the total aerosol absorption at $405 \mathrm{~nm}$ at a rural site in the PRD to $\mathrm{BrC}$; the authors found higher $\mathrm{BrC}$ contributions during fall, which they ascribed to biomass burning (BBOA) activities nearby. However, the $\mathrm{BrC}$ components responsible for light absorption remain relatively unknown; this hinders a thorough understanding of the relationships between optical properties and chemical characteristics and, in turn, the realization of a generalized framework that can be extended to other sources and regions.

In this work, we present simultaneous measurements of aerosol chemical composition and light absorption of aerosol particles at a suburban site downwind of Guangzhou in the PRD, China. Contributions of $\mathrm{BC}$ and $\mathrm{BrC}$ to total aerosol light absorption were differentiated and quantified using measurements from a seven-wavelength aethalometer. Sources of OA, which were determined using PMF analysis, were correlated to $\mathrm{BrC}$ light absorption to identify the major contributor(s) to short-wavelength light absorption. More detailed chemical characteristics, such as $\mathrm{N}$-containing ion fragments, the degree of unsaturation (indicated by the ion double bond equivalent, or ion DBE), and the degree of oxygenation (indicated by the number of oxygen atoms in ions), were also used to investigate the structural characteristics of $\mathrm{BrC}$ related to light absorption.

\section{Methodology}

\subsection{Sampling site}

We conducted field measurements at the Guangzhou Panyu Atmospheric Composition Station (GPACS, $23^{\circ} 00^{\prime} \mathrm{N}$, $113^{\circ} 21^{\prime} \mathrm{E}$ ), on the periphery of Guangzhou, China, from 7 November 2014 to 3 January 2015. The GPACS is located on top of a hill with an altitude of approximately $150 \mathrm{~m}$ a.s.l. (Cheung et al., 2016; Tan et al., 2013; Zou et al., 2015); it is approximately $15 \mathrm{~km}$ south of the city center and was downwind of the central city throughout the sampling period, during which north winds prevailed (Qin et al., 2017).

\subsection{Measurements and data analysis}

Aerosol light absorption was measured with a sevenwavelength aethalometer (Magee Scientific, model AE33) at $370,470,520,590,660,880$, and $950 \mathrm{~nm}$. Ambient air was 
drawn through a $2.5 \mu \mathrm{m}$ cutoff inlet at $2 \mathrm{~L} \mathrm{~min}^{-1}$ before entering the aethalometer; particles were collected on the filter substrate, and light attenuation at the wavelengths above was recorded continuously. A diffusion drier was used to dry the sampled air stream, which reduced the relative humidity of the air to below $30 \%$. The optical properties of the collected particles were determined by comparing light attenuation in particle-laden and particle-free filter areas (Weingartner et al., 2003). To convert aerosol particles' light attenuation coefficients at the filter substrate to the light absorption coefficients suspended in the air, a real-time compensation parameter $k$ and a fixed multiple scattering parameter $C$ were used. The real-time loading effect correction was performed using two parallel measurements of optical attenuations at different accumulation rates. $C_{\text {ref }}=2.14$ for quartz filter and $C_{\text {ref }}=1.57$ for tetrafluoroethylene (TFE)-coated glass filter were recommended from previously studies for the fresh soot particles (Drinovec et al., 2015; Weingartner et al., 2003). However, with the presence of semi-volatile oxidation products, significantly higher values $(C=3.6 \pm 0.6)$ were observed in the organic coating experiment using a quartz filter (Weingartner et al., 2003). Wavelength dependence of $C$ has also been reported in the literature (Arnott et al., 2005; Schmid et al., 2006; Segura et al., 2014). A broad range of $C$ (from 2.8 to 7.8 ) at several sites was also used by Collaud Coen et al. (2010). As the multiple scattering parameter $(C)$ may be site-specific, we further compared the absorption from the AE33 with cavity ring-down spectroscopy (CRD, Hexin XG-1000) and a nephelometer (TSI, 3563). The nephelometer was calibrated by $\mathrm{CO}_{2}$ weekly during the field campaign. Particle-free air was checked once a day. The CRD was calibrated using polystyrene spheres with known indices of refraction before the campaign. We extracted the light absorption based on extinction and scattering measurements from cavity ring-down spectroscopy and the nephelometer, respectively, as follows:

$b_{\mathrm{abs}}=\sigma_{\mathrm{ext}}-\sigma_{\mathrm{sp}}$,

where $b_{\mathrm{abs}}, \sigma_{\mathrm{ext}}$ and $\sigma_{\mathrm{sp}}$ are absorption coefficient, extinction coefficient and scattering coefficient.

The scatter plot of absorption at $532 \mathrm{~nm}$ from measurement from the aethalometer (AE33) and that calculated from CRD and the nephelometer is displayed in Fig. 1. The AE33 absorption coefficient was higher than the absorption estimated from Eq. (1) by a factor of 2.10. Therefore, the final multiple scattering parameter $(C)$ was set to $C_{\text {final }}=$ $C_{\text {ref }} \times 2.10=3.29$. This value is comparable with previous aethalometer measurements $(C=3.48)$ in the PRD region (Wu et al., 2009, 2013).

The non-refractory chemical composition of submicron aerosols was measured with an Aerodyne HR-ToF-AMS (Aerodyne Research Inc., Billerica, MA, USA). Briefly, the AMS collected 5 min average particle mass spectra for the high-sensitivity $\mathrm{V}$ plus particle time-of-flight (PToF) mode and the high-resolution $\mathrm{W}$ mode. AMS data analysis

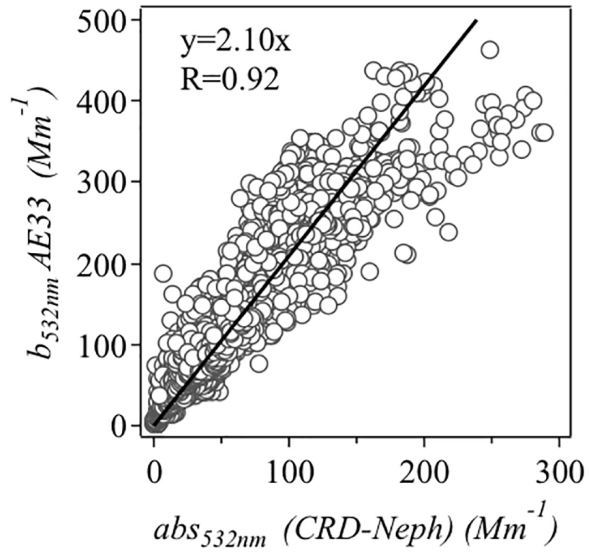

Figure 1. Scatter plot of absorption coefficients at $532 \mathrm{~nm}$ measured with an aethalometer (AE33) and those estimated from cavity ringdown spectroscopy (CRD) and nephelometer measurements.

was performed using the SQUIRREL (v1.56D) and PIKA (v1.15D) toolkits in Igor Pro (WaveMetrics Inc., Lake Oswego, OR, USA). Source apportionment was performed via PMF analysis with Multilinear Engine 2 (ME-2) via the SoFi interface (Canonaco et al., 2013). Five factors, including HOA, COA, BBOA, semi-volatile oxygenated organic aerosol (SVOOA), and low-volatility oxygenated organic aerosol (LVOOA), were resolved (Qin et al., 2017). The campaign-average OA composition was dominated by surrogates of SOA (SVOOA + LVOOA). However, freshly emitted hydrocarbon-like organic aerosols (HOA) contributed up to $40.0 \%$ of OA during high-OA periods; during nighttime, HOA contributed $23.8 \%$ to $28.4 \%$ on average. BBOA contributed $9.6 \%\left(1.87 \mu \mathrm{g} \mathrm{m}^{-3}\right)$ of total $\mathrm{OA}$ in November and $6.5 \%\left(1.38 \mu \mathrm{g} \mathrm{m}^{-3}\right)$ in December. AMS data treatment was discussed in detail in Qin et al. (2017). Data from a thermooptical elemental carbon and organic carbon (ECOC) analyzer (Sunset Laboratory Inc.) were also used for comparison.

\section{Results and discussion}

\subsection{Aerosol absorption}

Figure 2a shows the box-and-whisker plot of aerosol absorption coefficients $\left(b_{\mathrm{abs}}\right)$ from 370 to $950 \mathrm{~nm}$ from the aethalometer measurements during the campaign. The campaign-average absorption coefficients were $56.00 \mathrm{Mm}^{-1}$ at $370 \mathrm{~nm}, \quad 40.99 \mathrm{Mm}^{-1}$ at $470 \mathrm{~nm}, 34.76 \mathrm{Mm}^{-1}$ at $520 \mathrm{~nm}, 29.91 \mathrm{Mm}^{-1}$ at $590 \mathrm{~nm}, 26.69 \mathrm{Mm}^{-1}$ at $660 \mathrm{~nm}$, $18.06 \mathrm{Mm}^{-1}$ at $880 \mathrm{~nm}$, and $16.71 \mathrm{Mm}^{-1}$ at $950 \mathrm{~nm}$.

In multiwavelength absorption measurements, the total absorption Ångström exponent (AAE) can be calculated by a power-law fitting of the absorption coefficient over all available wavelengths. The AAE of unity has been widely used 

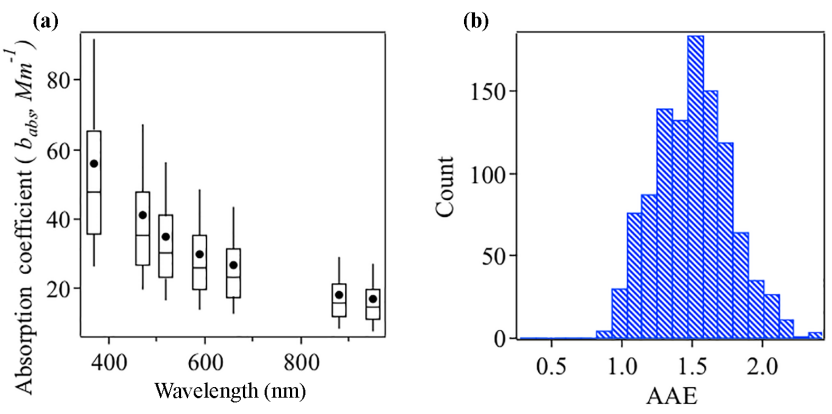

Figure 2. (a) Box-and-whisker plot of absorption coefficient at seven wavelengths as measured with the AE33. (b) Histogram of AAE values over the measurement campaign.

for pure black carbon, while a shift to a higher AAE value has been observed with the presence of brown carbon. The reason behind is that $\mathrm{BrC}$ has a much stronger absorption at $\mathrm{UV}$ and short visible wavelengths than at long visible wavelengths, which yields a steeper curve (Andreae and Gelencsér, 2006; Bergstrom et al., 2007; Bond and Bergstrom, 2006). The presence of non-absorbing OA shells over BC cores may also lead to a shift of the AAE (Gyawali et al., 2009). This latter possibility is analyzed in a separate paper (Li et al., 2018). Briefly, a Mie theory model was used to estimate the $\mathrm{AAE}$ for $\mathrm{BC}$-containing particles $\left(\mathrm{AAE}_{\mathrm{BC}}\right)$ in coreshell scenarios with different refractive indexes. $\mathrm{AAE}_{\mathrm{BC}}$ is sensitive to the specific refractive index of the core and shell of the particles and the size of the particle. The size distribution is from scanning mobility particle sizer and aerodynamic particle sizer measurement, and we vary the refractive index of the core and shell in the model. The method is adopted from Tan et al. (2016). In general, AAEBC increases as the real part refractive index of the core increases or the imaginary part decreases, or alternatively the real part of the shell increases. The $\mathrm{AAE}_{\mathrm{BC}}$ ranges from 0.67 to 1.03 across the different scenarios (Table S1 in the Supplement). As shown in Fig. $2 b$, the AAE values, which average at 1.43 , are almost always higher than 1, indicating appreciable contributions from $\mathrm{BrC}$ to particle light absorption at this site.

To further explore the importance of $\mathrm{BrC}$ at this site, $\mathrm{BrC}$ absorption at a short wavelength $\lambda_{1}\left(b_{\mathrm{BrC}, \lambda 1}\right)$ can be derived by subtracting $\mathrm{BC}$ absorption $\left(b_{\mathrm{BC}, \lambda 1}\right)$ from the total aerosol absorption (Lack and Langridge, 2013) via

$b_{\mathrm{BrC}, \lambda 1}=b_{\lambda 1}-b_{\mathrm{BC}, \lambda 1}$,

where absorption $b_{\lambda 1}$ is the measured absorption at the short wavelength $\lambda_{1}$. $\mathrm{BC}$ absorption at $\lambda_{1}\left(b_{\mathrm{BC}, \lambda 1}\right)$ can be obtained from the $\mathrm{AAE}$ value of $\mathrm{BC}\left(\mathrm{AAE}_{\mathrm{BC}}\right)$ via

$b_{\mathrm{BC}, \lambda 1}=b_{\lambda 2} \times\left(\lambda_{2} / \lambda_{1}\right)^{\mathrm{AAE}_{\mathrm{BC}}}$,

where $b_{\lambda 2}$ is the absorption at a longer wavelength $\lambda_{2}$ $(880 \mathrm{~nm})$, which is assumed to have no contributions from

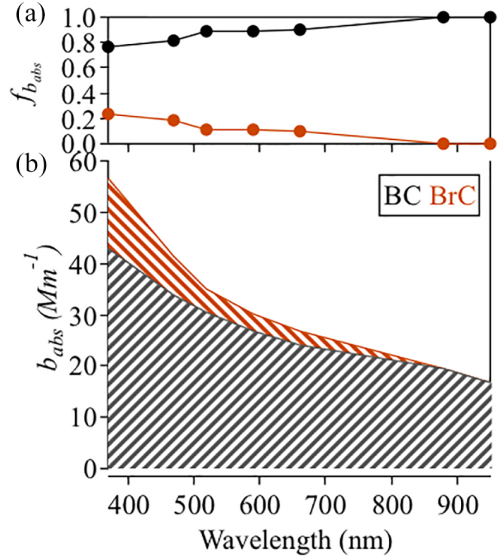

Figure 3. (a) Fractions of $\mathrm{BC}$ and $\mathrm{BrC}$ contributions to aerosol particle light absorption at different wavelengths. (b) Contributions of $\mathrm{BC}$ and $\mathrm{BrC}$ to the total light absorption coefficient at different wavelengths.

BrC or dust (Drinovec et al., 2015; Zhu et al., 2017). The uncertainty involved in attributing $\mathrm{BrC}$ and $\mathrm{BC}$ absorption at short wavelengths has been explored explicitly by Lack and Langridge (2013). This uncertainty is primarily from the uncertainty of choice of $\mathrm{AAE}_{\mathrm{BC}}$. Based on the $\mathrm{AAE}_{\mathrm{BC}}$ from the Mie theory model, a sensitivity analysis of BrC contribution to total light absorption is presented in the Supplement Fig. S1.

Figure 3 shows the $b_{\mathrm{abs}}$ attributed to $\mathrm{BC}$ and $\mathrm{BrC}\left(b_{\mathrm{BC}}\right.$ and $\left.b_{\mathrm{BrC}}\right)$ at different wavelengths. Aerosol light absorption coefficients were dominated by $\mathrm{BC}$, but $b_{\mathrm{BrC}}$ was not negligible, especially at short wavelengths. The campaign-average $b_{\mathrm{BrC}}$ values were $13.67,7.56,4.49,3.22$, and $2.81 \mathrm{Mm}^{-1}$ at $370,470,520,590$, and $660 \mathrm{~nm}$, respectively; BrC absorption contributed $23.6 \%, 18.1 \%, 10.7 \%, 10.7 \%$, and $10.5 \%$ of the total absorption at the corresponding wavelengths. The proportions of $\mathrm{BrC}$ and $\mathrm{BC}$ in our campaign were slightly higher than those reported in an earlier study in the PRD by Yuan et al. (2016). In their study, the average light absorption contributions of BrC during Shenzhen winter, Shenzhen fall, and Heshan fall campaigns were $11.7 \%, 6.3 \%$, and $12.1 \%$ at $405 \mathrm{~nm}$ and $10.0 \%, 4.1 \%$, and $5.5 \%$ at $532 \mathrm{~nm}$, respectively.

Figure 4 shows the diurnal variations of both $b_{\mathrm{BrC}}$ and $b_{\mathrm{BC}}$ at $370,470,520,590$, and $660 \mathrm{~nm}$, respectively. In general, the diurnal cycles of $b_{\mathrm{BrC}}$ and $b_{\mathrm{BC}}$ share similar patterns, indicating that they may have similar sources. However, it should be noted that some OA factors, such as BBOA and HOA, also share similar patterns (Qin et al., 2017). Overall, there were two peaks at each wavelength. The first peak appeared in the morning at around 08:00 LT, with a peak before 08:00 LT for longer wavelengths and after 08:00 LT for shorter wavelengths. The second peak appeared at 21:00 LT and its intensity decreased until 24:00 LT. These changes may be attributed to diurnal changes in $\mathrm{BrC}$ sources, which most likely originated from crop residual burning in fall and winter in 
nearby regions (Wang et al., 2017). The diurnal variations of the different wavelengths were not significantly different, although short wavelengths exhibited more obvious diurnal variations.

\subsection{Correlation of light absorption by $\mathrm{BrC}$ with $\mathrm{OA}$ components}

To explore the possible sources of $\mathrm{BrC}$, correlations were determined between $b_{\mathrm{BrC}}$ at $370 \mathrm{~nm}\left(b_{\mathrm{BrC}, 370}\right)$ and various OA types. Data at $370 \mathrm{~nm}$ were chosen (over data at longer wavelengths) for their higher signal-to-noise ratios and larger contributions of $\mathrm{BrC}$ to light absorption. Figure 5 shows that $\mathrm{BBOA}$ concentrations and $b_{\mathrm{BrC}, 370}$ were well correlated (Pearson's correlation coefficient, $R_{\mathrm{p}}=0.58$ ). More interestingly, a moderate correlation $\left(R_{\mathrm{p}}=0.40\right)$ was also found between $b_{\mathrm{BrC}, 370}$ and the LVOOA mass concentration. Although the LVOOA factor was not further resolved into OOA factors with biomass origins, it is likely that a portion of LVOOA was formed from biomass burning precursors through either gas-phase oxidation or heterogeneous reactions. Satish et al. (2017) found correlations between $\mathrm{BrC}$ absorption and both primary BBOA and BBOA-related SVOOA factors. They also reported that the slope of the correlation between $b_{\mathrm{BrC}, 370}$ and $\mathrm{BBOA}$ (slope $=1.35$ ) was 4.8 times higher than that between $b_{\mathrm{BrC}, 370}$ and one of the biomass burning SVOOA factors (slope $=0.28$ ), indicating that aging may have reduced the absorption capacity of biomass-related OA.

Multiple regression analysis was also used to resolve the correlation factors of each OA component $\left(\mathrm{m}^{2} \mathrm{~g}^{-1}\right)$ at each wavelength.

$$
\begin{aligned}
b_{\mathrm{BrC}} & =a \times[\mathrm{HOA}]+b \times[\mathrm{COA}]+c \times[\mathrm{BBOA}] \\
& +d \times[\mathrm{SVOOA}]+e \times[\mathrm{SVOOA}],
\end{aligned}
$$

where $a, b, c, d$, and $e$ indicate the correlation factors of each OA component $\left(\mathrm{m}^{2} \mathrm{~g}^{-1}\right)$ and [HOA], [COA], [BBOA], [SVOOA], and [SVOOA] indicate the mass concentration of each OA component. These correlation factors obtained are equivalent to the mass absorption coefficient (MAC) of each OA component. We will use these factors to compare with $\mathrm{MAC}$ reported in the literature later.

Washenfelder et al. (2015) reported a MAC of $1.3 \pm$ $0.06 \mathrm{~m}^{2} \mathrm{~g}^{-1}$ using the $b_{\mathrm{BrC}}$ at $365 \mathrm{~nm}$ for BBOA in the rural southeastern United States, which was 40 to 135 times higher than the MAC values reported for other OA factors. Di Lorenzo et al. (2017) found that both BBOA and more oxidized oxygenated organic aerosol (MO-OOA) were associated with water-soluble $\mathrm{BrC}$ and that the MAC of BBOA doubled that of MO-OOA. However, Forrister et al. (2015) observed that $\mathrm{BrC}$ in wildfire plumes had a lifetime of roughly 9 to $15 \mathrm{~h}$, probably due to conversion to SOA with lower light absorption capacity. In our study, the MAC (correlation factor in Table 1) of BBOA at $370 \mathrm{~nm}$ was $3.4 \pm 0.41 \mathrm{~m}^{2} \mathrm{~g}^{-1}$, roughly 3.4 times that of LVOOA $\left(1.04 \pm 0.08 \mathrm{~m}^{2} \mathrm{~g}^{-1}\right)$. Like the studies listed above (Forrister et al., 2015; Di Lorenzo et al., 2017; Washenfelder et al., 2015), our results suggest that the absorption coefficient of nascent BBOA is higher than that of its aged counterpart at short wavelengths. However, it should be noted that LVOOA might consist of some other non-absorbing SOA components with no biomass origin. It is therefore important to consider chromophore lifetimes when modeling light absorption by BrC. As noted in Laskin et al. (2015), the physicochemical properties of chromophores in $\mathrm{BrC}$ may exhibit dynamic changes that are not yet sufficiently understood. In addition, the difference between MAC values of BBOA and LVOOA decreased for longer wavelengths. The MAC values of BBOA were roughly 3.4, 1.8, 1.5, 1.48, and 0.80 times those of LVOOA at 370, 470,520,570, and $660 \mathrm{~nm}$, respectively. The contribution to total absorption coefficient also varied with wavelength. The contribution from BBOA decreased from $25.8 \%$ to $10.1 \%$ from 370 to $660 \mathrm{~nm}$, while the contribution from LVOOA increased from $49.3 \%$ to $60.2 \%$ from 370 to $660 \mathrm{~nm}$. The contribution of HOA was more stable across different wavelengths but was also significant, likely due to the high mass concentration of HOA. The exponential decay of $b_{\text {abs }}$ for different light-absorbing components was shown in Fig. 7. The fitted AAE values for those components are 3.52, 3.28, 5.50, and 2.67 for total $\mathrm{BrC}$, HOA, BBOA, and LVOOA respectively. These results indicate the variability of AAE values ranging from different sources which is likely inherent to the chemical variability of $\mathrm{BrC}$ constituents. Altogether, these observations indicate that the wavelength-dependent light absorption of different OAs must be considered in light absorption models.

\subsection{Correlation of $b_{\mathrm{BrC}}$ with $\mathrm{N}$-containing organic ions}

The chromophores in $\mathrm{BrC}$ that are responsible for OA light absorption are not well characterized. Structurally, light absorption depends on the extent of $\mathrm{sp}^{2}$ hybridization, in which $\pi$ electrons are usually found (Bond and Bergstrom, 2006). Of the elements commonly found in $\mathrm{OA}$, both $\mathrm{C}$ and $\mathrm{N}$ have strong tendencies toward $\mathrm{sp}^{2}$ hybridization. It has also been found that, despite their small OA mass fraction contributions, $\mathrm{N}$-containing organic species in $\mathrm{OA}$ can be responsible for appreciable light absorption (Chen et al., 2016; Laskin et al., 2015). Thus, we examined the correlations between $b_{\mathrm{BrC}}$ and $\mathrm{N}$-containing ions from AMS measurements. These ion fragments, including the $\mathrm{C}_{x} \mathrm{H}_{y} \mathrm{~N}^{+}$and $\mathrm{C}_{x} \mathrm{H}_{y} \mathrm{O}_{z} \mathrm{~N}^{+}$families, likely originated from $\mathrm{N}$-heterocyclic compounds. Figure 6 shows that the mass loadings of $\mathrm{C}_{x} \mathrm{H}_{y} \mathrm{~N}^{+}$and $\mathrm{C}_{x} \mathrm{H}_{y} \mathrm{O}_{z} \mathrm{~N}^{++}$ families are correlated with $b_{\mathrm{BrC}}$ at $370 \mathrm{~nm}$ and that correlations are stronger for fragments containing both $\mathrm{N}$ and $\mathrm{O}$ atoms. These results are consistent with Chen et al. (2016), who suggested that organic compounds with $\mathrm{O}$ and $\mathrm{N}$ atoms might contribute substantially to total light absorption and fluorescence in OA components. 
(a)

Diurnal variations of brown carbon $b_{B r C}$
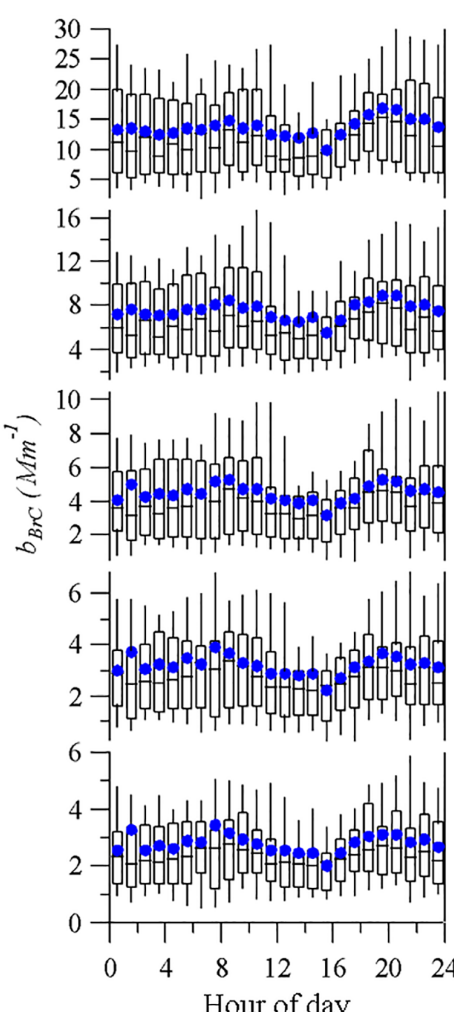

(b) Diurnal variations of black carbon $b_{B C}$
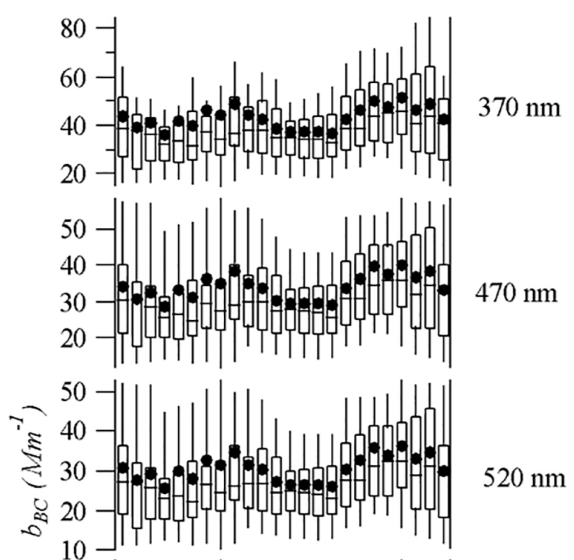

$590 \mathrm{~nm}$

$660 \mathrm{~nm}$
$590 \mathrm{~nm}$

$\mathrm{nm}$

(1)

$660 \mathrm{~nm}$
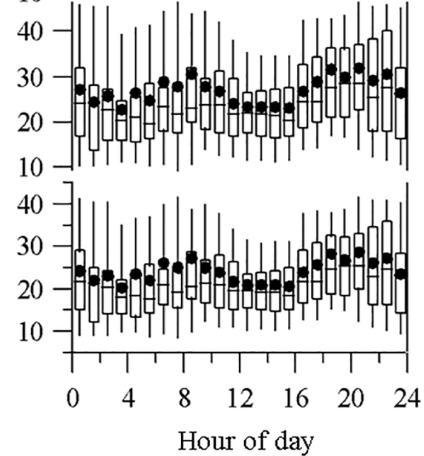

Figure 4. Diurnal variations of $\mathrm{BrC}$ and $\mathrm{BC}$ light absorption coefficients $\left(b_{\mathrm{BrC}}\right.$ and $\left.b_{\mathrm{BC}}\right)$ at different wavelengths.

Table 1. Multilinear regression analyses between $b_{\mathrm{BrC}}$ at each wavelength and mass loading of different OA factors from AMS-PMF/ME-2.

\begin{tabular}{|c|c|c|c|c|c|c|c|c|c|c|}
\hline & \multicolumn{2}{|c|}{$370 \mathrm{~nm}$} & \multicolumn{2}{|c|}{$470 \mathrm{~nm}$} & \multicolumn{2}{|c|}{$520 \mathrm{~nm}$} & \multicolumn{2}{|c|}{$590 \mathrm{~nm}$} & \multicolumn{2}{|c|}{$660 \mathrm{~nm}$} \\
\hline & $\begin{array}{r}\text { Correlation } \\
\text { factor } \\
\left(\mathrm{m}^{2} \mathrm{~g}^{-1}\right)\end{array}$ & $\begin{array}{r}\text { Contribution } \\
\text { to } \\
b_{\mathrm{BrC}}\end{array}$ & $\begin{array}{r}\text { Correlation } \\
\text { factor } \\
\left(\mathrm{m}^{2} \mathrm{~g}^{-1}\right)\end{array}$ & $\begin{array}{r}\text { Contribution } \\
\text { to } \\
b_{\mathrm{BrC}}\end{array}$ & $\begin{array}{r}\text { Correlation } \\
\text { factor } \\
\left(\mathrm{m}^{2} \mathrm{~g}^{-1}\right)\end{array}$ & $\begin{array}{r}\text { Contribution } \\
\text { to } \\
b_{\mathrm{BrC}}\end{array}$ & $\begin{array}{r}\text { Correlation } \\
\text { factor } \\
\left(\mathrm{m}^{2} \mathrm{~g}^{-1}\right)\end{array}$ & $\begin{array}{r}\text { Contribution } \\
\text { to } \\
b_{\mathrm{BrC}}\end{array}$ & $\begin{array}{r}\text { Correlation } \\
\text { factor } \\
\left(\mathrm{m}^{2} \mathrm{~g}^{-1}\right)\end{array}$ & $\begin{array}{r}\text { Contribution } \\
\text { to } \\
b_{\mathrm{BrC}}\end{array}$ \\
\hline HOA & $0.61 \pm 0.05$ & $22.7 \%$ & $0.38 \pm 0.03$ & $25.4 \%$ & $0.22 \pm 0.02$ & $24.5 \%$ & $0.16 \pm 0.02$ & $25.1 \%$ & $0.16 \pm 0.01$ & $27.9 \%$ \\
\hline $\mathrm{BBOA}$ & $3.4 \pm 0.41$ & $25.2 \%$ & $1.2 \pm 0.26$ & $15.9 \%$ & $0.63 \pm 0.18$ & $13.9 \%$ & $0.43 \pm 0.14$ & $13.4 \%$ & $0.21 \pm 0.11$ & $10.3 \%$ \\
\hline LVOOA & $1.04 \pm 0.08$ & $52.2 \%$ & $0.65 \pm 0.05$ & $58.7 \%$ & $0.41 \pm 0.04$ & $61.5 \%$ & $0.29 \pm 0.03$ & $61.5 \%$ & $0.26 \pm 0.02$ & $61.3 \%$ \\
\hline
\end{tabular}

Notes: (1) Correlation coefficient $(R)$ for each regression analysis: 0.65 at $370 \mathrm{~nm}, 0.58$ at $470 \mathrm{~nm}, 0.51$ at $520 \mathrm{~nm}, 0.51$ at $570 \mathrm{~nm}$, and 0.54 at $660 \mathrm{~nm}$. (2) The correlation factors for COA and SVOOA are near zero at all wavelengths, indicating a negligible contribution from these factors, so only the correlation factors for HOA, BBOA, and LVOOA are listed in the table.

The effects of oxygenation (as indicated by the number of $\mathrm{O}$ atoms in an ion) and unsaturation/cyclization (as indicated by the ion double bond equivalent, or ion DBE) were also examined for each $\mathrm{C}_{x} \mathrm{H}_{y} \mathrm{~N}^{+}$and $\mathrm{C}_{x} \mathrm{H}_{y} \mathrm{O}_{z} \mathrm{~N}^{+}$ion family. Several studies found that species with high DBE values may have a substantial network of conjugated double bonds and likely contribute to light absorption (Budisulistiorini et al., 2017; Laskin et al., 2014; Lin et al., 2016). The ion DBE represents the number of double bonds (unsaturation) or rings (cyclization) that an ion contains and is calculated on the basis of the elemental formula via the following equation:

$\mathrm{DBE}=\mathrm{C}+1-\mathrm{H} / 2-\mathrm{X} / 2+\mathrm{N} / 2$, where $\mathrm{C}, \mathrm{H}, \mathrm{X}$, and $\mathrm{N}$ are the number of carbon, hydrogen, halogen $(\mathrm{Cl}, \mathrm{Br}, \mathrm{I}$, and $\mathrm{F})$, and nitrogen atoms present in the ion, respectively.

Figure $8 \mathrm{a}$ shows the correlation coefficients between $\mathrm{bBrC}$ at all available wavelengths and the mass loadings of each ion in $\mathrm{C}_{x} \mathrm{H}_{y} \mathrm{~N}^{+}$and $\mathrm{C}_{x} \mathrm{H}_{y} \mathrm{NO}_{z}^{+}$families at different DBE values. For the $\mathrm{C}_{x} \mathrm{H}_{y} \mathrm{~N}^{+}$family, $R_{\mathrm{p}}$ increased as DBE increased across all wavelengths, suggesting that $\mathrm{bBrC}$ was better correlated with fragments with higher degrees of unsaturation or cyclization. An increasing trend of $R_{\mathrm{p}}$ as DBE increased is more obvious for short wavelengths (e.g., $\lambda$ at 370 and $470 \mathrm{~nm}$ ), suggesting that the absorption at short wavelengths is more associated with the unsaturation or cyclization. Indeed, in saturated organics, light absorption involves excita- 


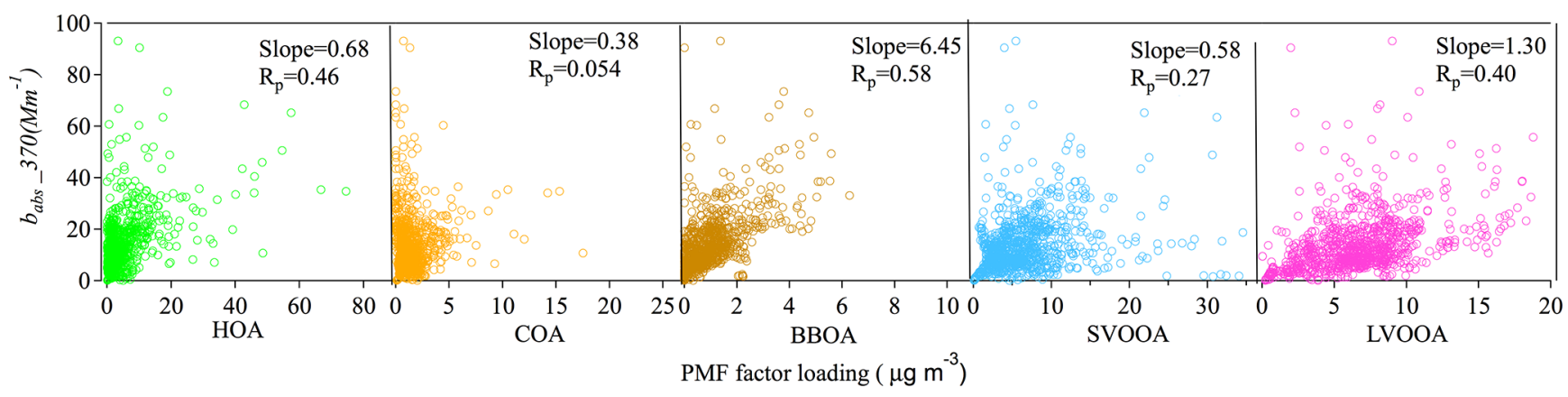

Figure 5. Correlations between the $\mathrm{BrC}$ absorption coefficients at $370 \mathrm{~nm}$ and the mass loadings of OA factors resolved by AMS-PMF/ME-2.
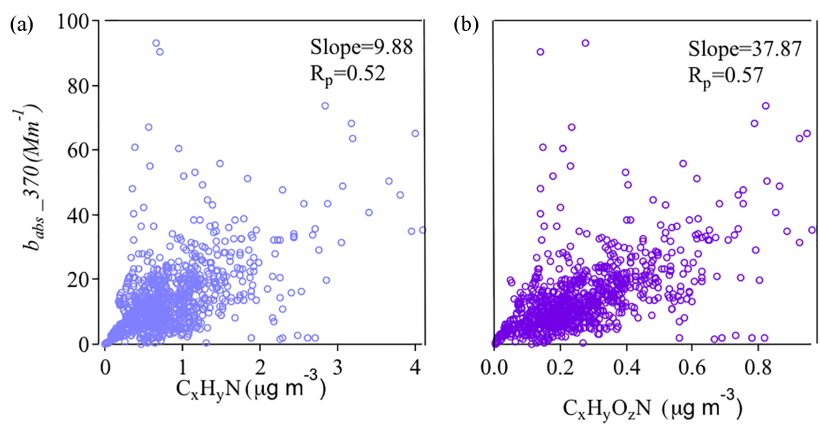

Figure 6. Correlations between $\mathrm{BrC}$ absorption coefficients at $370 \mathrm{~nm}$ and mass concentrations of $\mathrm{N}$-containing organic ion families.

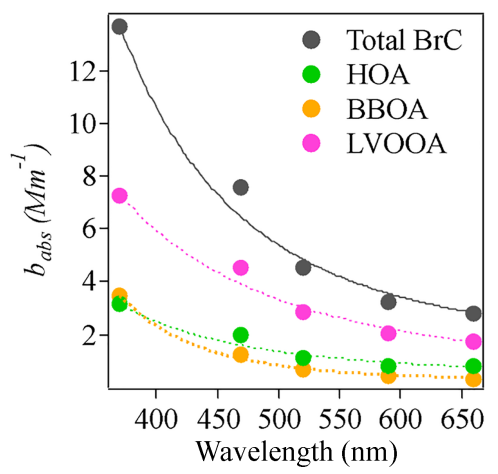

Figure 7. Exponential decay of $b_{\mathrm{abs}}$ for total $\mathrm{BrC}$ and different light-absorbing OA components across wavelengths.

tion of $n$ electrons, which requires more energy and, therefore, shorter incident wavelengths (e.g., short UV). In unsaturated organics, the delocalized $\pi$ electrons are in clusters of $\mathrm{sp}^{2}$ hybrid bonds and in longer conjugated systems, such that the energy difference between the excited state and the ground state goes down, which makes the absorption band shift to longer wavelengths. These structural features may explain in part the increased correlation between mass loadings of the $\mathrm{C}_{x} \mathrm{H}_{y} \mathrm{~N}^{+}$family and light absorption with decreasing ion saturation. For the $\mathrm{C}_{x} \mathrm{H}_{y} \mathrm{NO}_{z}^{+}$family, we did not
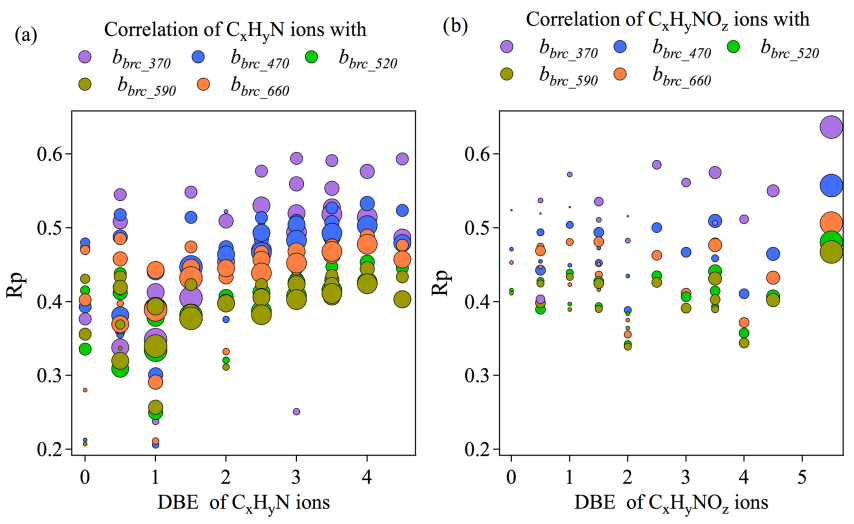

Figure 8. Correlation coefficients between $\mathrm{BrC}$ absorption coefficient across different wavelengths and $\mathrm{N}$-containing organic ion fragments grouped by double bond equivalence (a, b). Larger grey dots correspond to higher carbon numbers.

observe obvious trends in the correlation coefficient with a changing degree of saturation/cyclization (Fig. 8b). This phenomenon is consistent across different wavelengths. However, the overall Pearson's $R_{\mathrm{p}}$ values of $b_{\mathrm{BrC}}$ with $\mathrm{C}_{x} \mathrm{H}_{y} \mathrm{NO}_{z}^{+}$ were higher than those with $\mathrm{C}_{x} \mathrm{H}_{y} \mathrm{~N}^{+}$. The $R_{\mathrm{p}}$ for each group of ions is higher at short wavelengths ( $\lambda$ at 370 and $470 \mathrm{~nm}$ ).

\section{Conclusions}

This paper presents collocated, real-time atmospheric particle light absorption and chemical composition measurements at a suburban site in PRD, China. While BC dominated aerosol light absorption, $\mathrm{BrC}$ also contributed to absorption at short wavelengths. The aerosol light absorption coefficients of $\mathrm{BrC}$ were 13.67, 7.56, 4.49, 3.22, and $2.81 \mathrm{Mm}^{-1}$ at $370,470,520,590$, and $660 \mathrm{~nm}$, respectively, and $\mathrm{BrC}$ contributed $23.6 \%, 18.1 \%, 10.7 \%, 10.7 \%$, and $10.5 \%$ of the total absorption at the corresponding wavelengths. Hydrocarbon-like organic aerosol (HOA), biomass burning organic aerosol (BBOA), and low-volatility oxygenated organic aerosol (LVOOA) were also substantial for the source of $\mathrm{BrC}$. At a short wavelength $(370 \mathrm{~nm})$, the mass 
absorption coefficient of BBOA was higher than that of HOA and LVOOA. However, the difference between the mass absorption coefficients of BBOA and other OA factors decreased with increasing wavelength. The contribution of different OA sources to total absorption coefficient also varied with wavelength. Such a wavelength-dependent trend is also observed for their contribution to total $\mathrm{BrC}$ absorption coefficients. $\mathrm{C}_{x} \mathrm{H}_{y} \mathrm{~N}^{+}$and $\mathrm{C}_{x} \mathrm{H}_{y} \mathrm{O}_{z} \mathrm{~N}^{+}$were likely the chromophores responsible for the observed $\mathrm{BrC}$ light absorption. The mass loadings of $\mathrm{C}_{x} \mathrm{H}_{y} \mathrm{~N}^{+}$and $\mathrm{C}_{x} \mathrm{H}_{y} \mathrm{O}_{z} \mathrm{~N}^{+}$ion families became better correlated with the $\mathrm{BrC}$ light absorption coefficient as their degrees of unsaturation/cyclization and oxygenation increased. This study shows wavelength-dependent light absorption by $\mathrm{BrC}$ is strongly influenced by moderately specific molecular characteristics such as degrees of unsaturation/cyclization and oxygenation. An exploration of the absorptive properties of more specific molecular features, such as the chemical identities of $\mathrm{BrC}$ constituents, would require a more detailed chemical characterization of the highly complex OA composition.

Data availability. The data are available upon request. To obtain the data, please contact Chak K. Chan (chak.k.chan@ @ityu.edu.hk) or Yong Jie Li (yongjieli@umac.mo).

Supplement. The supplement related to this article is available online at: https://doi.org/10.5194/acp-18-16409-2018-supplement.

Author contributions. CC and HT initialized and designed the field campaign. YQ and MB collected the AMS data. HT, ZL, and LL contributed to the collection of AE33 data and provided auxiliary data. CW contributed to data quality control of AE33. YQ analyzed the data and wrote the paper. YL and CC contributed to the important scientific considerations in analysis of the data and also wrote the paper. All listed authors took part in scientific discussions relating to this paper.

Competing interests. The authors declare that they have no conflict of interest.

Acknowledgements. This work was supported by the National Key Project of the Ministry of Science and Technology of the People's Republic of China (2016YFC0201901, 2016YFC0203305). We thank Jianhuai Ye for fruitful discussions. Chak K. Chan would like to acknowledge the Science Technology and Innovation Committee of Shenzhen municipality (project no. 41675117). Yong Jie Li gratefully acknowledges support from the Science and Technology Development Fund of Macau (FDCT-136/2016/A3).

Edited by: Alexander Laskin

Reviewed by: three anonymous referees

\section{References}

Andreae, M. O. and Gelencsér, A.: Black carbon or brown carbon? The nature of light-absorbing carbonaceous aerosols, Atmos. Chem. Phys., 6, 3131-3148, https://doi.org/10.5194/acp-63131-2006, 2006.

Arnott, W. P., Hamasha, K., Moosmüller, H., Sheridan, P. J., and Ogren, J. A.: Towards aerosol light-absorption measurements with a 7-wavelength aethalometer: Evaluation with a photoacoustic instrument and 3-wavelength nephelometer, Aerosol Sci. Tech., 39, 17-29, https://doi.org/10.1080/027868290901972, 2005.

Bergstrom, R. W., Pilewskie, P., Russell, P. B., Redemann, J., Bond, T. C., Quinn, P. K., and Sierau, B.: Spectral absorption properties of atmospheric aerosols, Atmos. Chem. Phys., 7, 5937-5943, https://doi.org/10.5194/acp-7-5937-2007, 2007.

Bond, T. C. and Bergstrom, R. W.: Light Absorption by Carbonaceous Particles: An Investigative Review, Aerosol Sci. Tech., 40, 27-67, https://doi.org/10.1080/02786820500421521, 2006.

Budisulistiorini, S. H., Riva, M., Williams, M., Chen, J., Itoh, M., Surratt, J. D., and Kuwata, M.: Light-Absorbing Brown Carbon Aerosol Constituents from Combustion of Indonesian Peat and Biomass, Environ. Sci. Technol., 51, 4415-4423, https://doi.org/10.1021/acs.est.7b00397, 2017.

Canonaco, F., Crippa, M., Slowik, J. G., Baltensperger, U., and Prévôt, A. S. H.: SoFi, an IGOR-based interface for the efficient use of the generalized multilinear engine (ME2) for the source apportionment: ME-2 application to aerosol mass spectrometer data, Atmos. Meas. Tech., 6, 3649-3661, https://doi.org/10.5194/amt-6-3649-2013, 2013.

Chan, C. K. and Yao, X.: Air pollution in mega cities in China, Atmos. Environ., 42, 1-42, https://doi.org/10.1016/j.atmosenv.2007.09.003, 2008.

Chen, Q., Ikemori, F., and Mochida, M.: Light Absorption and Excitation-Emission Fluorescence of Urban Organic Aerosol Components and Their Relationship to Chemical Structure, Environ. Sci. Technol., 50, 10859-10868, https://doi.org/10.1021/acs.est.6b02541, 2016.

Cheung, H. H. Y., Tan, H., Xu, H., Li, F., Wu, C., Yu, J. Z., and Chan, C. K.: Measurements of non-volatile aerosols with a VTDMA and their correlations with carbonaceous aerosols in Guangzhou, China, Atmos. Chem. Phys., 16, 8431-8446, https://doi.org/10.5194/acp-16-8431-2016, 2016.

Collaud Coen, M., Weingartner, E., Apituley, A., Ceburnis, D., Fierz-Schmidhauser, R., Flentje, H., Henzing, J. S., Jennings, S. G., Moerman, M., Petzold, A., Schmid, O., and Baltensperger, U.: Minimizing light absorption measurement artifacts of the Aethalometer: evaluation of five correction algorithms, Atmos. Meas. Tech., 3, 457-474, https://doi.org/10.5194/amt-3-4572010, 2010.

Di Lorenzo, R. A., Washenfelder, R. A., Attwood, A. R., Guo, H., Xu, L., Ng, N. L., Weber, R. J., Baumann, K., Edgerton, E., and Young, C. J.: Molecular-Size-Separated Brown Carbon Absorption for Biomass-Burning Aerosol at Multiple Field Sites, Environ. Sci. Technol., 51, 3128-3137, https://doi.org/10.1021/acs.est.6b06160, 2017.

Drinovec, L., Mocnik, G., Zotter, P., Prévôt, A. S. H., Ruckstuhl, C., Coz, E., Rupakheti, M., Sciare, J., Müller, T., Wiedensohler, A., and Hansen, A. D. A.: The "dual-spot" Aethalometer: an improved measurement of aerosol black carbon with real- 
time loading compensation, Atmos. Meas. Tech., 8, 1965-1979, https://doi.org/10.5194/amt-8-1965-2015, 2015.

Feng, Y., Ramanathan, V., and Kotamarthi, V. R.: Brown carbon: a significant atmospheric absorber of solar radiation?, Atmos. Chem. Phys., 13, 8607-8621, https://doi.org/10.5194/acp13-8607-2013, 2013.

Forrister, H., Liu, J., Scheuer, E., Dibb, J., Ziemba, L., Thornhill, K. L., Anderson, B., Diskin, G., Perring, A. E., Schwarz, J. P., Campuzano-Jost, P., Day, D. A., Palm, B. B., Jimenez, J. L., Nenes, A., and Weber, R. J.: Evolution of brown carbon in wildfire plumes, Geophys. Res. Lett., 42, 4623-4630, https://doi.org/10.1002/2015GL063897, 2015.

Gen, M., Huang, D., and Chan, C. K.: Reactive uptake of glyoxal by ammonium containing salt particles as a function of relative humidity, Environ. Sci. Technol., 52, 6903-6911, https://doi.org/10.1021/acs.est.8b00606, 2018.

Gong, Z., Lan, Z., Xue, L., Zeng, L., He, L., and Huang, X.: Characterization of submicron aerosols in the urban outflow of the central Pearl River Delta region of China, Front. Environ. Sci. En., 6, 725-733, https://doi.org/10.1007/s11783-012-0441-8, 2012.

Gyawali, M., Arnott, W. P., Lewis, K., and Moosmüller, H.: In situ aerosol optics in Reno, NV, USA during and after the summer 2008 California wildfires and the influence of absorbing and nonabsorbing organic coatings on spectral light absorption, Atmos. Chem. Phys., 9, 8007-8015, https://doi.org/10.5194/acp-9-80072009, 2009.

He, L.-Y., Huang, X.-F., Xue, L., Hu, M., Lin, Y., Zheng, J., Zhang, R., and Zhang, Y.-H.: Submicron aerosol analysis and organic source apportionment in an urban atmosphere in Pearl River Delta of China using high-resolution aerosol mass spectrometry, J. Geophys. Res., 116, D12304, https://doi.org/10.1029/2010JD014566, 2011.

Huang, X.-F., He, L.-Y., Hu, M., Canagaratna, M. R., Kroll, J. H., Ng, N. L., Zhang, Y.-H., Lin, Y., Xue, L., Sun, T.L., Liu, X.-G., Shao, M., Jayne, J. T., and Worsnop, D. R.: Characterization of submicron aerosols at a rural site in Pearl River Delta of China using an Aerodyne High-Resolution Aerosol Mass Spectrometer, Atmos. Chem. Phys., 11, 18651877, https://doi.org/10.5194/acp-11-1865-2011, 2011.

Lack, D. A. and Langridge, J. M.: On the attribution of black and brown carbon light absorption using the Ångström exponent, Atmos. Chem. Phys., 13, 10535-10543, https://doi.org/10.5194/acp-13-10535-2013, 2013.

Laskin, A., Laskin, J., and Nizkorodov, S. a.: Chemistry of Atmospheric Brown Carbon, Chem. Rev., 115, 4335-4382, https://doi.org/10.1021/cr5006167, 2015.

Laskin, J., Laskin, A., Roach, P. J., Slysz, G. W., Anderson, G. A., Nizkorodov, S. A., Bones, D. L., and Nguyen, L. Q.: High-Resolution Desorption Electrospray Ionization Mass Spectrometry for Chemical Characterization of Organic Aerosols, Anal. Chem., 82, 2048-2058, https://doi.org/10.1021/ac902801f, 2010.

Laskin, J., Laskin, A., Nizkorodov, S. A., Roach, P., Eckert, P., Gilles, M. K., Wang, B., Lee, H. J., and Hu, Q.: Molecular selectivity of brown carbon chromophores, Environ. Sci. Technol., 48, 12047-12055, https://doi.org/10.1021/es503432r, 2014.

Li, Y. J., Sun, Y., Zhang, Q., Li, X., Li, M., Zhou, Z., and Chan, C. K.: Real-time chemical characterization of atmospheric particu- late matter in China?: A review, Atmos. Environ., 158, 270-304, https://doi.org/10.1016/j.atmosenv.2017.02.027, 2017.

Li et al.: Optical absorption properties of brown carbon in the Pearl River Delta region in China, in preparation, 2018.

Lin, P., Aiona, P. K., Li, Y., Shiraiwa, M., Laskin, J., Nizkorodov, S. A., and Laskin, A.: Molecular Characterization of Brown Carbon in Biomass Burning Aerosol Particles, Environ. Sci. Technol., 50, 11815-11824, https://doi.org/10.1021/acs.est.6b03024, 2016.

Liu, P. F., Abdelmalki, N., Hung, H.-M., Wang, Y., Brune, W. H., and Martin, S. T.: Ultraviolet and visible complex refractive indices of secondary organic material produced by photooxidation of the aromatic compounds toluene and $m$-xylene, Atmos. Chem. Phys., 15, 1435-1446, https://doi.org/10.5194/acp15-1435-2015, 2015.

Qin, Y. M., Tan, H. B., Li, Y. J., Schurman, M. I., Li, F., Canonaco, F., Prévôt, A. S. H., and Chan, C. K.: Impacts of traffic emissions on atmospheric particulate nitrate and organics at a downwind site on the periphery of Guangzhou, China, Atmos. Chem. Phys., 17, 10245-10258, https://doi.org/10.5194/acp-17-102452017, 2017.

Rincón, A. G., Guzmán, M. I., Hoffmann, M. R., and Colussi, A. J.: Optical Absorptivity versus Molecular Composition of Model Organic Aerosol Matter, J. Phys. Chem. A, 113, 10512-10520, https://doi.org/10.1021/jp904644n, 2009.

Satish, R., Shamjad, P., Thamban, N., Tripathi, S., and Rastogi, N.: Temporal Characteristics of Brown Carbon over the Central Indo-Gangetic Plain, Environ. Sci. Technol., 51, 6765-6772, https://doi.org/10.1021/acs.est.7b00734, 2017.

Schmid, O., Artaxo, P., Arnott, W. P., Chand, D., Gatti, L. V., Frank, G. P., Hoffer, A., Schnaiter, M., and Andreae, M. O.: Spectral light absorption by ambient aerosols influenced by biomass burning in the Amazon Basin. I: Comparison and field calibration of absorption measurement techniques, Atmos. Chem. Phys., 6, 3443-3462, https://doi.org/10.5194/acp-6-3443-2006, 2006.

Segura, S., Estellés, V., Titos, G., Lyamani, H., Utrillas, M. P., Zotter, P., Prévôt, A. S. H., Mocnik, G., Alados-Arboledas, L., and Martínez-Lozano, J. A.: Determination and analysis of in situ spectral aerosol optical properties by a multiinstrumental approach, Atmos. Meas. Tech., 7, 2373-2387, https://doi.org/10.5194/amt-7-2373-2014, 2014.

Sun, H., Biedermann, L., and Bond, T. C.: Color of brown carbon?: A model for ultraviolet and visible light absorption by organic carbon aerosol, Geophys. Res. Lett., 34, 1-5, https://doi.org/10.1029/2007GL029797, 2007.

Tan, H., Yin, Y., Gu, X., Li, F., Chan, P. W., Xu, H., Deng, X., and Wan, Q.: An observational study of the hygroscopic properties of aerosols over the Pearl River Delta region, Atmos. Environ., 77, 817-826, https://doi.org/10.1016/j.atmosenv.2013.05.049, 2013.

Tan, H., Liu, L., Fan, S., Li, F., Yin, Y., Cai, M., and Chan, P. W. Aerosol optical properties and mixing state of black carbon in the Pearl River Delta, China, Atmos. Environ., 131, 196-208, https://doi.org/10.1016/j.atmosenv.2016.02.003, 2016.

Wang, Y., Hu, M., Lin, P., Guo, Q., Wu, Z., Li, M., Zeng, L., Song, Y., Zeng, L., Wu, Y., Guo, S., Huang, X., and He, L.: Molecular Characterization of Nitrogen-Containing Organic Compounds in Humic-like Substances Emitted from Straw Residue Burning, Environ. Sci. Technol., 51, 5951-5961, https://doi.org/10.1021/acs.est.7b00248, 2017. 
Washenfelder, R. A., Attwood, A. R., Brock, C. A., Guo, H., Xu, L., Weber, R. J., Ng, N. L., Allen, H. M., Ayres, B. R., Baumann, K., Cohen, R. C., Draper, D. C., Duffey, K. C., Edgerton, E., Fry, J. L., Hu, W. W., Jimenez, J. L., Palm, B. B., Romer, P., Stone, E. A., Wooldridge, P. J., and Brown, S. S.: Biomass burning dominates brown carbon absorption in the rural southeastern United States, Geophys. Res. Lett., 42, 653-664, https://doi.org/10.1002/2014GL062444, 2015.

Weingartner, E., Saathoff, H., Schnaiter, M., Streit, N., Bitnar, B., and Baltensperger, U.: Absorption of light by soot particles: Determination of the absorption coefficient by means of aethalometers, J. Aerosol Sci., 34, 1445-1463, https://doi.org/10.1016/S0021-8502(03)00359-8, 2003.

Wu, D., Mao, J. T., Deng, X. J., Tie, X. X., Zhang, Y. H., Zeng, L. M., Li, F., Tan, H. B., Bi, X. Y., Huang, X. Y., Chen, J., and Deng, T.: Black carbon aerosols and their radiative properties in the Pearl River Delta region, Sci. China Ser. D, 52, 1152-1163, https://doi.org/10.1007/s11430-009-0115-y, 2009.

Wu, D., Wu, C., Liao, B., Chen, H., Wu, M., Li, F., Tan, H., Deng, T., Li, H., Jiang, D., and Yu, J. Z.: Black carbon over the South China Sea and in various continental locations in South China, Atmos. Chem. Phys., 13, 12257-12270, https://doi.org/10.5194/acp-13-12257-2013, 2013.
Yan, C., Zheng, M., Bosch, C., Andersson, A., Desyaterik, Y., Sullivan, A. P., Collett, J. L., Zhao, B., Wang, S., He, K., and Gustafsson, Ö.: Important fossil source contribution to brown carbon in Beijing during winter, Sci. Rep., 7, 43182, https://doi.org/10.1038/srep43182, 2017.

Yuan, J.-F., Huang, X.-F., Cao, L.-M., Cui, J., Zhu, Q., Huang, C.N., Lan, Z.-J., and He, L.-Y.: Light absorption of brown carbon aerosol in the PRD region of China, Atmos. Chem. Phys., 16, 1433-1443, https://doi.org/10.5194/acp-16-1433-2016, 2016.

Zhu, C.-S., Cao, J.-J., Hu, T.-F., Shen, Z.-X., Tie, X.X., Huang, H., Wang, Q.-Y., Huang, R.-J., Zhao, Z.-Z., Močnik, G., and Hansen, A. D. A.: Spectral dependence of aerosol light absorption at an urban and a remote site over the Tibetan Plateau, Sci. Total Environ., 590-591, 14-21, https://doi.org/10.1016/j.scitotenv.2017.03.057, 2017.

Zou, Y., Deng, X. J., Zhu, D., Gong, D. C., Wang, H., Li, F., Tan, H. B., Deng, T., Mai, B. R., Liu, X. T., and Wang, B. G.: Characteristics of 1 year of observational data of VOCs, $\mathrm{NO}_{x}$ and $\mathrm{O}_{3}$ at a suburban site in Guangzhou, China, Atmos. Chem. Phys., 15, 6625-6636, https://doi.org/10.5194/acp-15-6625-2015, 2015. 